\title{
In vitro Antagonistic Activity of Trichoderma harzianum against Rhizoctonia solani The Causative Agent of Potato Black Scurf and Stem Canker
}

\author{
Mohsen E. Ibrahim ${ }^{\#}$ \\ Department of Botany, Faculty of Science, University of Port Said, Port Said,42524, \\ Egypt.
}

\begin{abstract}
N EGYPT Potato (Solanum tuberosum L.) is considered one of the most important vegetable crops as well as many others countries in the world. It plays an important role in the Egyptian agricultural economy, not for local consumption but also for exportation especially to Europe, Russia and Arabic countries. However, potato crop suffer from more than 40 pests and diseases caused by insects, nematodes, viruses, bacteria and fungi, of which black scurf and stem canker induced by Rhizoctonia solani is probably the most serious disease. The world yield losses caused by $R$. solani were estimated to $5-15 \%$. $R$. solani is an unspecialized parasite, survive in soil in the absence of host plant and make itself a very difficult pathogen to manage. Reduction or elimination of soil borne inoculum is the only effective solution to overcome the problem and this may be achieved through the application of various control measures of which fungal antagonists consider among the most important tactic. Although $R$. solaniis usually controlled through the application of chemicals, the serious ecological and financial toll of this fungus has prompted for research on biopesticides as a viable alternative. Trichoderma spp. were well-known fungi often used for the biological control of crop pests, whose anti-fungal mechanisms include competition for the substrate, antibiosis and/or mycoparasitism. Five isolates of Trichoderma harzianum were tested in vitro for their antagonistic potential against Rhizoctonia solani. Both Trichoderma harzianum and Rhizoctonia solani were identified by molecular and morphological methods. In dual culture of all isolates were found antagonistic to the growth of $R$. solani. The hyphal interaction studied using light microscopy revealed destructive mycoparasitism of $R$. solani by $T$. harzianum. The method of mycoparasitism was sparse to intense coiling of $R$. solani followed by disintegration, disorganization and death of R. solani mycelium.
\end{abstract}

Keywords: Potato, Black scurf, Rhizoctonia solani, Biocontrol, Trichoderma spp.

\section{Introduction}

The Food and Agriculture Organization (FAO) proposed highlighting the potato (Solanum tuberosum L.) for (1) Its key role in the world global food system as it is the world's fourth most produced food commodity, (2) Its ability to grow worldwide, (3) Its convenience for farming systems in developing countries - potato crops harbour a high ratio of yield productivity to soil occupation $(85 \%$ of the plant is comestible compared with only $50 \%$ in cereals), and (4) Its nutritive qualities, with a higher amount of vitamins than grass plants (FAO, 2008).
Potato however, suffer from many pets of which stem canker and black scurf diseases caused by Rhizoctonia solani Kuhn (teleomorph, Thanatephorus cucumeris (A. B. Frank, Donk), consider one of the most important cosmopolitan necrotrophic soil-borne fungus. These diseases have worldwide distribution wherever potato is grown but their etiology varies depending on the predominance of distinct $R$. solani anastomosis groups (AGs) in a particular area. Although the disease is superficial on tuber, negative economic impact of sclerotia on potato, both as a tuber blemish and a source of inoculum on seed and in soil is very important and considered. 
On worldwide basis different anastomosis groups (AGs) of $R$. solani that have different virulence level associated with potato stem canker and black scurf diseases, has been identified (Jehtonen, 2009). AG3 group of $R$. solani is responsible disease in potato however the other anastomosis groups such as AG-2 type 1, AG-2 type 2, AG-4 and AG-5 are also included in infection both in tuber and stems (Demirci \& Doken, 1993). Several researchers now recognize $R$. solani as a complex of species which can be best delimitedon the basis of their hyphal fusion i.e. anastomosis (Anderson, 1982; Ogoshi, 1987 and Balali et al., 1995). In general, these groups of species share the following characteristics: (i) Multinucleate cells, pale to dark brown pigment, rapidly growing mycelium of relatively large diameter with branching near the distal septum of hyphae, (ii) Formation of monilioidcells which are barrel-shaped cells, chain of these cells aggregate to produce vegetative resting structure, the sclerotia, (iii) Sclerotia are usually of uniform texture and of varying size and shape, and (iv) Lack of conidiaand sexual spores.

Planning to control Rhizoctonia diseases are restricted because of its ecological behavior. It is extremely wide host range, having high survival rate of sclerotia under various environmental condition (Grosch et al., 2006).Moreover, cultivars with complete resistance are not available at now (Li et al., 1995). Thence, effective strategies to control the pathogen are demanding. In the other hand, increasing use of chemical application causes several negative effects, such as the development of pathogen resistance to the applied agents and their non-target environmental impacts (Gerhardson, 2002). A growing awareness of agricultural practices in using chemicals have a great impact on human health and on the environment has spawned research into the development of effective biocontrol agents to protect crop against diseases.

Application of antagonistic fungi as biological control agents is considered a non-polluting approach for alternative plant protection. This biological control relies on a reduction of the pathogen population size by the control organism, thus keeping pathogen density below the threshold necessary for disease formation. There is now unequivocal evidence that antibiotics and/or direct parasitism play a key role in the suppression of various soil-borne plant pathogens by antagonistic microorganisms (Braun et al., 2010 and Wensing et al., 2010).
Diverse species belonging to the genus Trichoderma are capable of parasitizing fungal plant pathogens such as $R$. solani, producing antibiotics effective against soil-borne pathogens and competing for infection sites against pathogens (Bénítez et al., 2004 and Vinale et al., 2008). Trichoderma virens and T. harzianum have been shown to be effective at controlling stem canker and black scurf, as well as increasing tuber yield (Tsror et al., 2001; Brewer \& Larkin, 2005; Wilson et al., 2008a and 2008b).). Kurzawińska (2006) also demonstrated an antagonistic effect of several Trichoderma species on Helminthosporium solani, providing evidence for the potential suppression of silver scurf by Trichoderma. Wang et al. (2009) reported that the use of an antagonistic microorganism of a Bacillus sp. strain CHM1 against $R$. solani on horse bean (Vicia faba), and Kumar et al. (2013) who also reported a Bacillus sp. strain N antagonized $R$. solani, Fusarium oxysporum, and Penicillium expansum. R.solani causes various kinds of diseases on such as bottom rot on lettuce, black scurf on potato, damping-off of cucumber, pine, and tomato (Tunlid et al., 1989; Huang et al., 2012 and Golinska \& Dahm, 2013).

Comprehension the mechanisms of biological control of plant diseases through the interactions between antagonists and pathogens may allow us to select and construct the more effective biocontrol agents and to manipulate the soil environment to create a conducive condition for successful biocontrol. The mechanisms of biocontrol may involve and be divided into (i) Antibiosis, (ii) Competition, (iii) Mycoparasitism, (iv) Cell wall degrading enzymes, and (v) Induced resistance. However, these mechanisms of biological control are probably never mutually exclusive. They may include one and more processes (Adams, 1990).

The aim of the present study was to isolate and identify fungal biota as well as testing strains of Trichoderma harzianum isolated from healthy and infected potato tubers to determine the efficacy of their potentiality as biocontrol agents against $R$. solani causative agent of potato stem canker and black scurf under laboratory conditions (in vitro).

\section{$\underline{\text { Materials and Methods }}$}

\section{Source of potato tubers}

Samples of potato (cultivar spounta) showing typical symptoms were taken from different parts 
of plant (stem, tuber, root, stolon and sprout) were collected from Ismailia Governorate (El-Shabab Region). Some fields were examined randomly through potato plantation (summer crop). The samples were transferred to laboratory in tight polyethylene bags and kept at low temperature until plating out; for isolation of the black scurf causal agent and other tuber associate fungal biota.

\section{Isolation of Rhizoctonia solani}

Pieces of potato plant (stem, tuber, root, stolon) that showed symptoms of $R$. solani disease were submerged in $2 \%$ sodium hypochlorite for $3 \mathrm{~min}$ then soaked in $70 \%$ ethanol for $1 \mathrm{~min}$ (Melgarejo et al., 1985). After rinsing with sterile water several times, infected potato tuber peel were divided into small pieces, transferred to plates of potato-dextrose-agar (PDA) supplemented by Rose bengal and chloramphenicol and incubated at $28^{\circ} \mathrm{C}$ for four days. Plates were daily observed for mycelial growth (Fig. 1). Hyphal tips emerging from the peel pieces, were transferred to fresh plates of PDA and CYA (Czapek's yeast extract agar). The isolated $R$. solani strains were stored at $5^{\circ} \mathrm{C}$ in slant containing PDA.

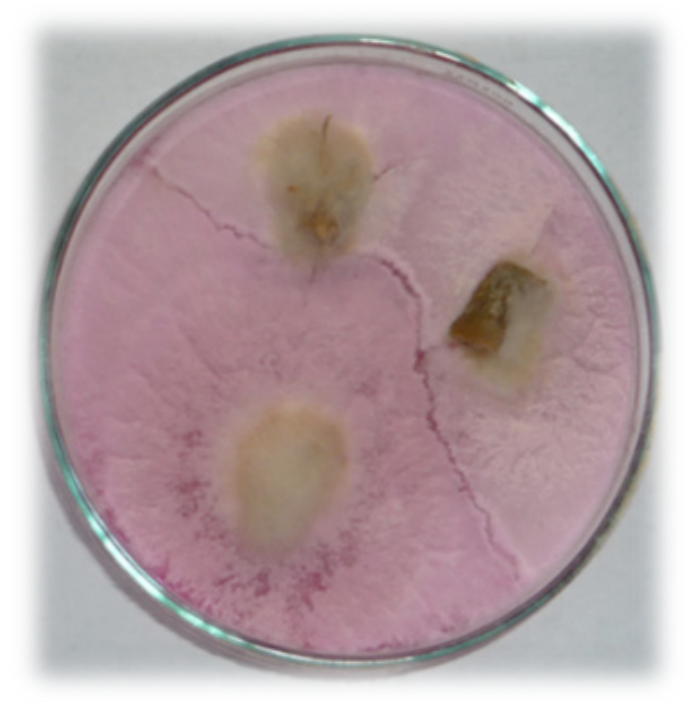

Fig. 1. Plate containing isolated Rhizoctonia showing hyphal growth.

\section{Disease Incidence}

Fifty potato tubers were randomly selected from each surveyed location to determine disease incidence using formula proposed by Ahmed et al. (1995):
Disease Incidence (black scurf) $=\frac{\text { No.of tubers infected }}{\text { Total Tubers Observed }} \times 100$

Disease severity

Black scurf severity disease was determined by using 0-5 disease severity grades based on percent tuber surface showing disease symptoms (Ahmed et al., 1995).

\section{Isolation of fungal biota}

The dilution plate technique as described by Waksman (1927) was adopted throughout this investigation for isolation and counting of fungal biota associated with healthy and infested potato tubers.Czapek's Yeast Extract Agar (CYA) supplemented with a combination of rose bengal (1/15.000) and Chloramphenicol (50 ppm) to suppress bacterial growth was elected during this study where it showed the best diversity as well as the most reasonable colony count. For each tubers sample six plates has been prepared thereafter incubated at $29^{\circ} \mathrm{C}$, after 7 days, growing colonies were identified and counted.

Morphological identification of $R$. solani \& $T$. harzianum

Macro-morphology (colony diameter, colony color, reverse and exudates) and micro-morphology (conidia \& phialides if present, mycelium) of both $R$. solani \& $T$. harzianum were used as criterions for Morphological identification of the fungal biota.

\section{Antagonistic efficiency of Trichoderma isolates}

Fifth Trichoderma harzianum strains were selected from the isolated fungi based on prior in vitro and in vivo $R$. solani suppression, or on their previous success in controlling plant diseases, including soil-borne plant pathogens in other biocontrol programs.

Trichoderma harzianum isolates from healthy and infested potato tubers were tested in a dual culture assay against $R$. solani representing AG-3 (isolate RS -1), which was recovered from potato tubers infected by black scurf. The isolates were cultivated in Petri dishes with PDA media for seven days. Disks of $5 \mathrm{~mm}$ of diameter were cut and removed from the growing borders of the colonies and transferred to another Petri dish with PDA. Each plate received two disks, one with Trichoderma mycelium and another with Rhizoctonia mycelium, placed at a distance of $7 \mathrm{~cm}$ from each other, in time intervals according the growth speed test organisms. The plates were incubated at $29{ }^{\circ} \mathrm{C}$ for five days in according to the growth rate of 
the two competitors. The experiment was entirely at random with three replicates. The percentage inhibition of radial growth $\mathrm{I}=[(\mathrm{C}-\mathrm{T}) / \mathrm{C}] \times 100$ of $R$. solani and the width of the zone of inhibition between both colonies were recorded as described by Royse \& Ries (1978). Mode of inhibition was assessed on a scale from 1 to 4 , in which $1=$ Mycelial growth of $R$. solani ceased due to overgrowth of $T$. harzianum, $2=$ Partial inhibition of $R$. solani and interacting fungus but both grow slowly over each other, $3=$ Mutual inhibition at a distance $<2 \mathrm{~mm}, 4=$ Growth of $R$. solani inhibited at a distance $>2 \mathrm{~mm}$ (Chand \& Logan, 1984).

$$
\mathrm{I}=[(\mathrm{C}-\mathrm{T}) / \mathrm{C}] \times 100
$$

where, I = Inhibition of radial mycelial growth; $\mathrm{C}=$ Pathogen Radial growth measurement in control; $\mathrm{T}=$ Pathogen radial growth in the presence of Trichoderma spp.

\section{Molecular identification of $R$. solani and $T$. harzianum}

Anastomosis group identification of $R$. solani

Isolates were assigned to AGs by conventional PCR assays using specific primers for AG3 , sequencing of the ITS-rDNA and hyphal interactions.

Mycelium for DNA extraction from $R$. solani isolates was obtained from six days old cultures on PDA. After incubation at room temperature, mycelium was harvested by scraping the mycelia from the surface of PDA plates, followed by freezing and lyophilization. DNA was extracted with a QIAGEN ${ }^{\circledR}$ DNeasy Plant Mini-Kit. The anastomosis group was determined by selective amplification of the ribosomal DNA (rDNA) region using specific primers for $R$. solani AG-3 (Lees et al., 2002). Polymerase chain reactions (PCR) were carried out in $10 \mu \mathrm{l}$ volumes containing 10-50 ng of genomic DNA, $10 \mathrm{mM}$ of $\mathrm{KCl}, 10 \mathrm{mM}$ of $\left(\mathrm{NH}_{4}\right)_{2} \mathrm{SO}_{4}, 20 \mathrm{mM}$ of Tris- $\mathrm{HCl}$, $2 \mathrm{mM}$ of $\mathrm{MgSO}_{4}, 0.01 \%$ of Triton X-100, $\mathrm{pH} 8.8$ (NEB), $0.2 \mu \mathrm{M}$ of each primer (Microsynth), 0.1 $\mathrm{mM}$ of each dNTP and $0.06 \mathrm{U}$ of Taq polymerase (NEB). PCR conditions comprised initial denaturation of $2 \mathrm{~min}$ at $96^{\circ} \mathrm{C}$, followed by 35 cycles of denaturation for $30 \mathrm{~s}$ at $96^{\circ} \mathrm{C}$, annealing for $45 \mathrm{~s}$ at $57^{\circ} \mathrm{C}$ and elongation for $45 \mathrm{~s}$ at $72^{\circ} \mathrm{C}$, with a final extension step of $5 \mathrm{~min}$ at $72^{\circ} \mathrm{C}$. In both cases, PCR products were visualized with UV on agarose gels.
Genomic DNA extraction from Trichoderma strains

Genomic DNA was extracted from the mycelium of Trichoderma isolates using the method described by Wijesinghe et al. (2010).

PCR amplification of ITS region of Trichoderma isolates

To confirm the species of strain Trichoderma at the molecular level, ITS region was amplified using universal primers ITS 1(5'-TCTGTAGGTGAACCTGCGG3') and ITS 4(5'-TCCTCCGCTTATTGATATGC-3') according to White et al. (1990) and Gardes \& Bruns (1993). Genomic DNA was amplified using a DNA thermal cycler of Applied BioSystems (USA).The reaction mixture contains $38.5 \mu$ ldeionized water, $5 \mu 110 \mathrm{X}$ Taq polymerase buffer, $0.5 \mu \mathrm{l}$ of $1 \mathrm{U}$ Taq polymerase enzyme, $3 \mu \mathrm{l} 2 \mathrm{mM}$ dNTPs, $1 \mu \mathrm{l}$ of 100 $\mathrm{mM}$ reverse and forward primers and $1 \mu \mathrm{l}$ of $50 \mathrm{ng}$ template DNA. PCR conditions were as follows; an initial denaturation of $3 \mathrm{~min}$ at $94^{\circ} \mathrm{C}$ followed by 35 cycles of $1 \mathrm{~min}$ denaturation at $94^{\circ} \mathrm{C}, 1 \mathrm{~min}$ primer annealing at $50{ }^{\circ} \mathrm{C}, 1 \mathrm{~min}$ extension at 72 ${ }^{\circ} \mathrm{C}$ and a final extension of $10 \mathrm{~min}$ at $72{ }^{\circ} \mathrm{C}$. PCR products were checked by electrophoresis using $2 \%$ agarose gel in $1 \mathrm{X}$ TAE buffer.

\section{Results}

Results of surveyed fields showed that the prevalence of disease at all visited areas. The above-ground parts of potato plants showed aerial tubers, rolling of leaves and chlorosis before harvesting while the most obvious symptoms of the black scurf were observed as sclerotial masses on tubers after harvesting of crop (Fig. 2).

Data of Table 1 clearly showed that maximum disease incidence for black scurf and stem canker was $(23 \%$ and $26 \%)$ in field no. 4, minimum was $(8 \%$ and $9 \%)$ in field no. 1.Data represent the average of two consecutive years 2013/2014 in surveyed fields.

Black scurf severity disease was determined by using 0-5 disease severity grades based on percent tuber surface showing disease symptoms (Ahmed et al., 1995), where: $0=$ no symptoms on the potato tubers, $1=$ less than $1 \%$ of the tuber area affected, $2=1-10 \%$ of the tuber area affected, $3=11-20 \%$ of the tuber area affected, $4=21-51 \%$ of the tuber area affected and $5=51 \%$ or more of the tuber area affected (Fig. 3). 
TABLE. 1. Percentage of potato stem canker and black scurf in investigated fields.

\begin{tabular}{|c|c|c|c|c|c|}
\hline \multirow[t]{2}{*}{ Governorate } & \multirow[t]{2}{*}{ Season } & \multirow[t]{2}{*}{ Field No. } & \multirow[t]{2}{*}{ Potato cultivar } & \multicolumn{2}{|c|}{$\begin{array}{c}\text { \% of disease incidence } \\
2013 \text { / } 2014\end{array}$} \\
\hline & & & & Black scurf & Stem canker \\
\hline \multirow{5}{*}{ Ismailia } & & 2 & & 17.6 & 16.3 \\
\hline & & 3 & & 18.6 & 17.6 \\
\hline & & 5 & & 12.3 & 13 \\
\hline & & 6 & & 17 & 15.3 \\
\hline & & 7 & & 14.3 & 16.3 \\
\hline $\operatorname{LSD}(0.05 \%)$ & & & & 5.96 & 4.5 \\
\hline
\end{tabular}
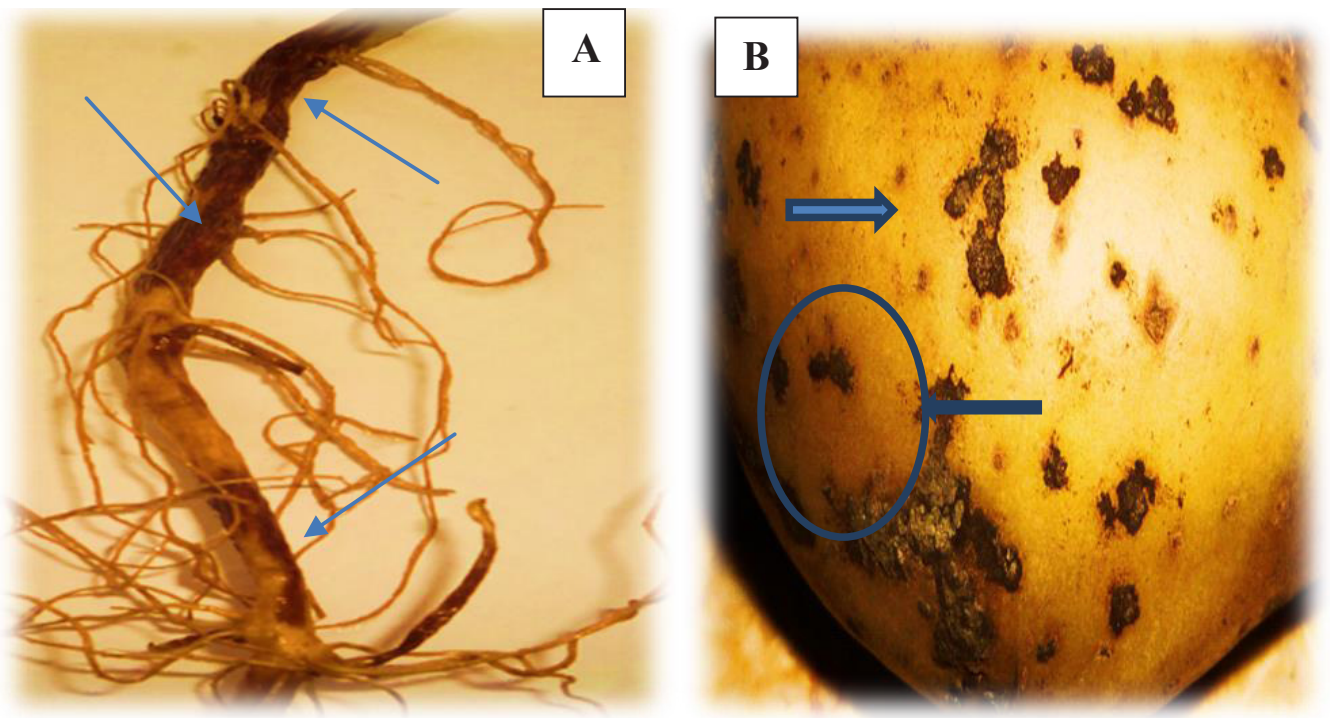

Fig. 2. Symptoms of $R$. solani infected potato plant and tuber.

A- Lesions of stem canker (arrows), $X=25 \quad$ B- Sclerotia on tuber (arrows), $X=25$.

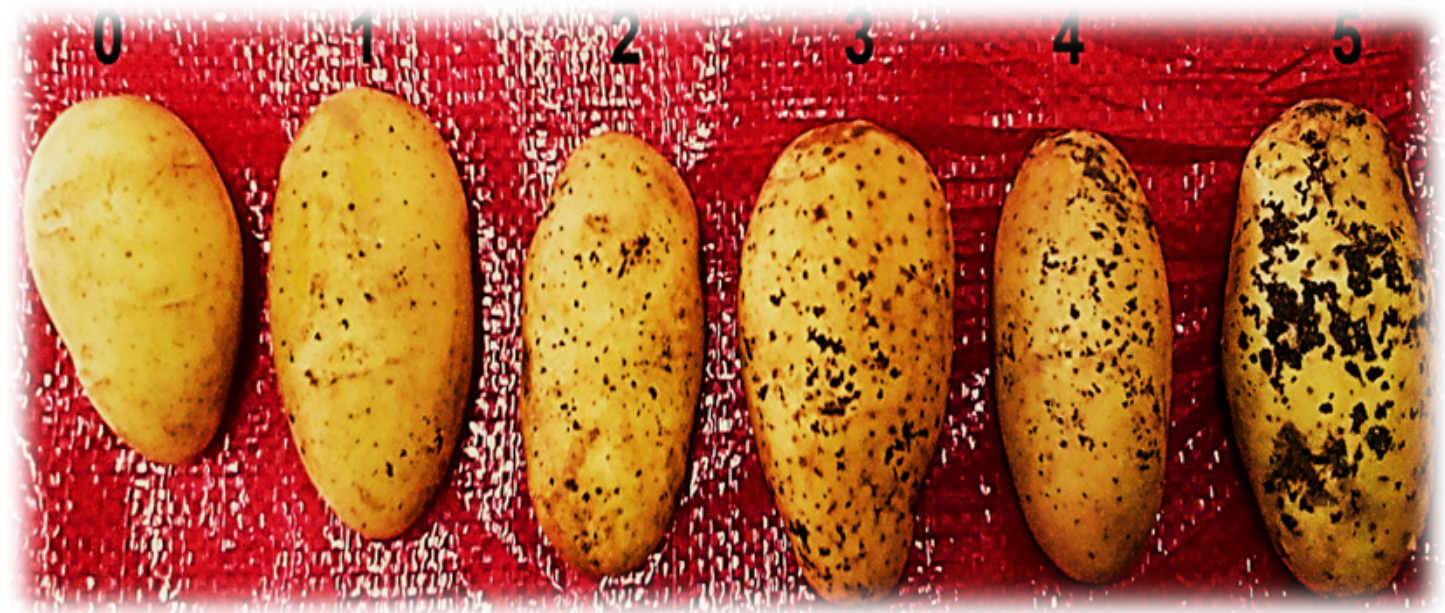

Fig. 3: Black scurf index in potato according to Ahmad et al. (1995), $X=25$. 
The Rhizoctonia solani was initially identified by the presence of thread-like whitish mycelial growth, which gradually turned to dark brown followed by production of sclerotia on the culture that seemed to be submerged in the agar plates; large aggregates of sclerotia were spherical and irregularly shaped (Fig. 4).
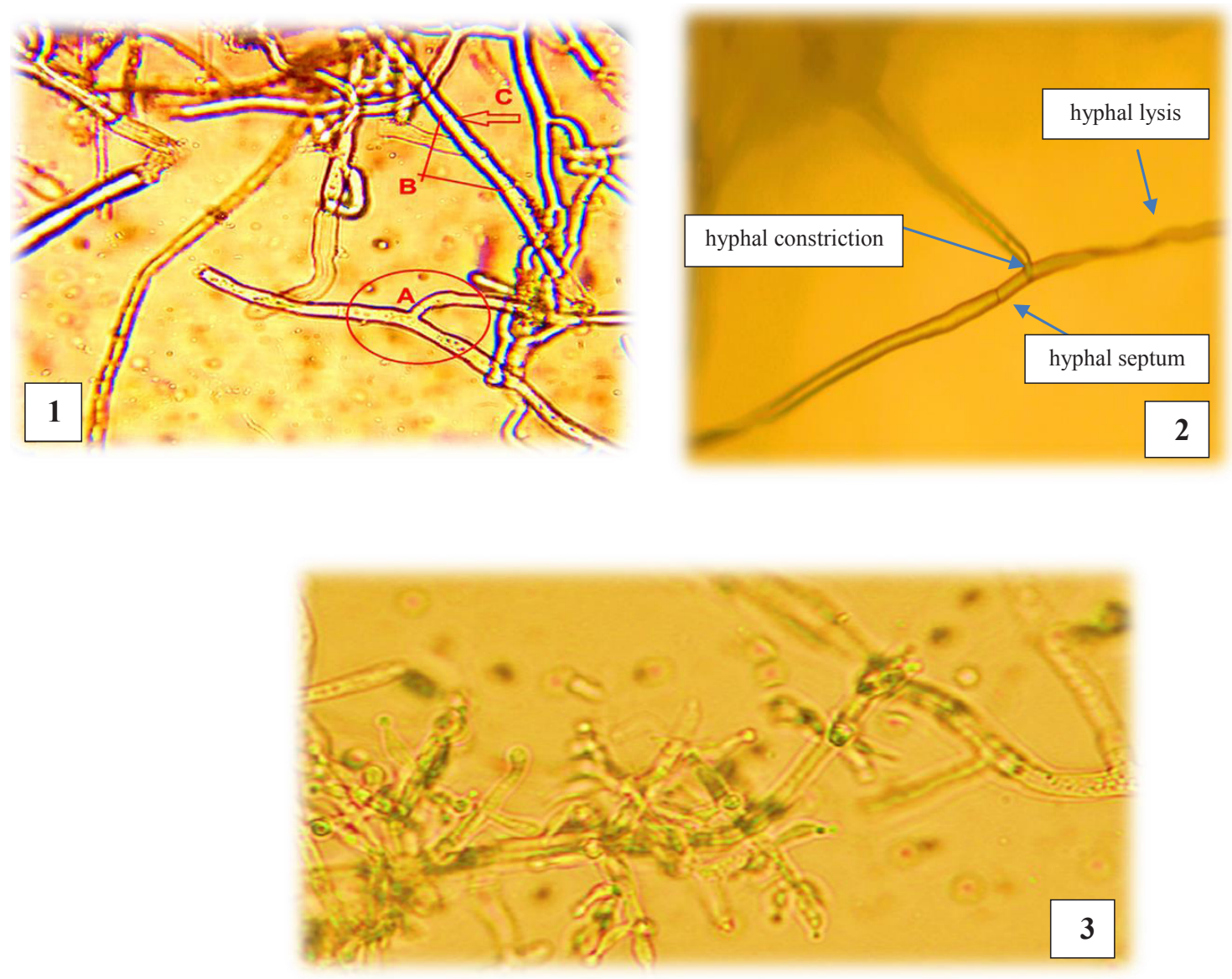

Fig. 4. Morphological characteristics to $R$. solani and $T$. harzianum under light microscope (1): A branching hypha B- septum $C$ - main hyphae $(X=25 \%)$ septum (arrow; $X=25 \%$ ).

(3): T. harzianum phialides \& conidia $(X=50 \%)$.

\section{Fungal biota of healthy and infected tuber}

A spectrum of 14 genera represented by 23 species have been reported from the peel tubers of healthy and infected potato tubers (Table 2). In view of total count the most abundant species comprise the following taxa (in decreasing order of dominance): Aspergillus niger, A. terreus. A. flavus, A. versicolor, Fusarium solani, Penicillium chrysogenum, Cladosporium cladosporioides, Scopulariopsis brevicaulis and Botryotrichum piluliferum. These species are common to both healthy and infected tubers but with some difference in the order of dominance.

Antagonistic efficiency of Trichoderma isolates

Data of in vitro dual culture clearly demonstrated that all five tested $T$. harzianum isolates were potentially active against $R$. solani with a ratio ranged from $67 \%$ to $73 \%$. Some strains overgrowth upon $R$. solani with producing clear zone (Fig. 5 a), other strains overgrowth on target pathogen with formation of coiling around $R$. solani mycelium as well as lysis of hyphae (Fig. 5 b, c, d).

Molecular identification of $R$. solani and $T$. harzianum

Data of PCR and DNA sequencing proved that most $R$. solani isolates evaluated were assigned to AG-3PT (99\%), while almost Trichoderma isolates were allocated to T. harzianum (98\% to $99 \%$ ). 
TABLE 2. Mean count (cfu/g) ${ }^{*}$ and frequency of fungal biota isolated from healthy and infected potato tubers.

\begin{tabular}{|c|c|c|c|c|c|}
\hline \multirow{2}{*}{ No. } & \multirow{2}{*}{$\begin{array}{l}\text { Potato tuber } \\
\text { Fungal species }\end{array}$} & \multicolumn{2}{|c|}{ Healthy tuber } & \multicolumn{2}{|c|}{ Infected tuber } \\
\hline & & Count $^{* *}$ & Frequency $\%$ & Count $^{* *}$ & Frequency \% \\
\hline 1 & Aspergillus niger & 87 & 85 & 83 & 71 \\
\hline 2 & A. terreus & 65 & 71 & 80 & 57 \\
\hline 3 & A. flavus & 43 & 57 & 94 & 85 \\
\hline 4 & A. versicolor & 46 & 43 & 65 & 57 \\
\hline 5 & Fusarium solani & 68 & 43 & 25 & 29 \\
\hline 6 & Penicillium chrysogenum & 52 & 43 & 7 & 29 \\
\hline 7 & Cladosporium cladosporioides & 18 & 43 & 21 & 43 \\
\hline 8 & Scopulariopsis brevicaulis & 16 & 29 & 23 & 14 \\
\hline 9 & Botryotrichum piluliferum & 15 & 29 & 21 & 29 \\
\hline 10 & Penicillium citrinum & 33 & 29 & - & - \\
\hline 11 & Chaetomium globosum & 19 & 29 & 6 & 14 \\
\hline 12 & Penicillium sp. & 17 & 14 & 5 & 14 \\
\hline 13 & Trichoderma harzianum & 11 & 43 & 6 & 57 \\
\hline 14 & A. ochraceus & 13 & 14 & - & - \\
\hline 15 & Fusarium oxysporum & - & - & 13 & 43 \\
\hline 16 & Gliocladium roseum & 9 & 29 & - & - \\
\hline 17 & Emericella nidulans & 8 & 14 & - & - \\
\hline 18 & Absidia corymbifera & - & - & 7 & 43 \\
\hline 19 & Chaetomium sp. & 6 & 14 & - & - \\
\hline 20 & Acremonium terricola & 3 & 29 & 2 & 14 \\
\hline 21 & Paecilomyces variotii & - & - & 5 & 29 \\
\hline 22 & Trichoderma koningii & - & - & 5 & 29 \\
\hline 23 & Myrothecium sp. & - & - & 3 & 14 \\
\hline
\end{tabular}

$*(\mathrm{cfu} / \mathrm{g})=$ Colony forming unit

${ }^{* *}$ Mean of 7 samples. 


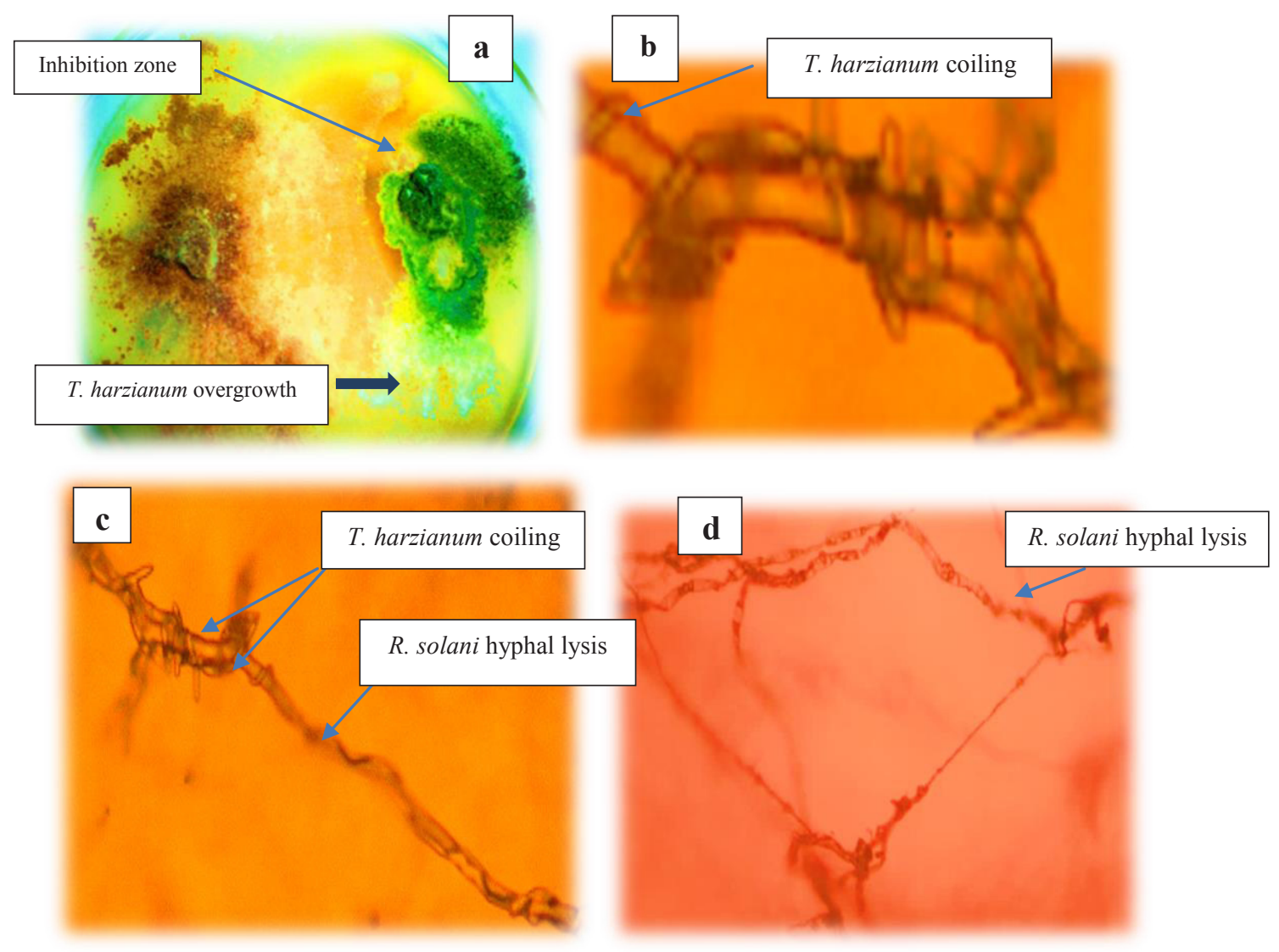

Fig. 5. Antagonistic efficiency of T. harzianum isolates against $R$. solani

i: (a) plate show inhibition zone \& overgrowth $(X=12.5 \%)$. ii: $(b, c, d)$ interaction between the two opponent coiling of $T$. harzianum hyphae around $R$. solani hyphae (mycoparasitism $X=200 \%, 100 \mid \%) \&$ hyphal lysis of $R$. solani $(\mathrm{X}=\mathbf{2 5 \%})$

\section{Discussion}

R. solani is widespread and responsible for severe damage to many worldwide economically important agricultural and horticultural crops (Grosch et al., 2006). As for potato high yield losses were reported reaching up to $20 \%$ (Grosch et al., 2005). Strategies to control Rhizoctonia diseases are limited because of its ecological behavior. Control of the pathogen is difficult because of its ecological behavior, extremely broad host range and the high survival rate of sclerotia under various environmental conditions (Groth \& Bond, 2006). In agriculture, crop protection depend heavily on chemical pesticides. However, there is a growing concern for negative health and environmental effects of such pesticides. Biological control is an alternative strategy which may provide effective and sustainable control of $R$. solani on potato or other host crops (Larkin \& Brewer, 2005).
Indeed, a lot of fungal biota have been reported to be effective biocontrol agents of $R$. solani on potato. Among these are species of Gliocladium (Papavizas, 1985 and Van den Boogert, 1996), Trichoderma (Brewer \& Larkin, 2005; Grosch et al., 2006 and Wilson et al., 2008a), and Verticillium (Jager \& Velvis 1985 and Turhan, 1990). Chaetomium olivaceum, Cylindrocarpon destructans, Epicoccum nigrum, Gliocladium viride, Gliocladium roseum, Penicillium cyclopium, Penicillium nigricans, Trichoderma harzianum, and Trichothecium roseum were frequently isolated from sclerotia of $R$. solani (Chand \& Logan, 1984).

In Egypt diverse T. harzianum isolates have been shown to be effective antagonists of $R$. solani. These isolates contain many mycoparasitic strains that are considered good biocontrol agents against soil-borne pathogens. However, many investigators reported that within the genus Trichoderma, species such as $T$. hamatum, $T$. 
harzianum, T. reesei, T. virens, and T. viride have demonstrated efficient antagonistic activity against $R$. solani under laboratory conditions as well as under pots and field conditions (Chand \& Logan, 1984; Beagle-Ristaino \& Papavizas, 1985; Brewer \& Larkin, 2005; Grosch et al., 2006 and Wilson et al., 2008a). Trichoderma isolates are well adapted to survival in crop soils, compatible with the indigenous soil microflora, and capable of colonizing the zone immediately adjacent to plants roots. Trichoderma spp. are mycoparasitic on $R$. solani (Elad et al., 1983). In addition, T. harzianum isolates are known to secrete several extracellular enzymes which are potentially antagonistic to $R$. solani (Bertagnolli et al., 1996). The first event in decay of fungal pathogens, however, may be due to the secretion of small molecular weight antifungal compounds by the Trichoderma spp. (Benhamou \& Chet, 1996).

During this investigation twenty three fungal taxa, representing different frequency classes, have been isolated. Among these taxa there are many species having antagonistic potentiality against plant pathogens and $R$. solani viz: Penicillium spp., Chaetomium spp., Trichoderma spp., Acremonium sp. And Gliocladium sp. All isolated T. harzianum ( 5 isolates) have been tested on agar plates, for their ability to antagonize the target organism ( $R$. solani AG-3PT). Results of screening tests revealed that the antagonistic potentiality of T. harzianum isolates differ one strain to another by showing maximum inhibition ranged between $67 \%$ and $73 \%$.

In pair culture technique, some $T$. harzianum succeeded to surround the target organism colony completely and prevented it from any radial spread i.e. the tested candidates strains were unable to produce antifungal antibiotics but were able to compete with the pathogen for nutrients (especially carbon) and for space. The hyphal interaction studied using light microscopy revealed destructive mycoparasitism of $R$. solani by $T$. harzianum. The method of mycoparasitism was sparse to intense coiling of $R$. solani followed by disintegration, disorganization and death of $R$. solani mycelium.

Another third finding an inhibition zone was observed, which indicates the presence of fungistatic metabolites secreted by these fungi. Ahmad \& Baker (1987) and Ghisalberti \& Sivasithamparam (1991) have been demonstrated that the capacity of some Trichoderma isolates to produce antifungal compounds which inhibit the growth of the soil-borne fungal pathogen $R$. solani is a useful property to exploit in the use of Trichoderma isolates as biocontrol agents. A biocontrol agent may act against pathogens by using one or more of the following mechanisms: competition, antibiosis, and parasitism as well as activating host defense mechanisms (Papavizas \& Lumsden, 1980).

Results of the present study agree with the finding of many researchers all over the world as well as in Egypt: several species belonging to the genus Trichoderma are capable of parasitizing fungal plant pathogens such as $R$. solani, producing antibiotics effective against soil-borne pathogens and competing for infection sites against pathogens (Bénítez et al., 2004 and Vinale et al., 2008). T. virens and $T$. harzianum have been shown to be effective at controlling stem canker and black scurf, as well as increasing tuber yield (Tsror et al., 2001; Brewer \& Larkin, 2005 and Wilson et al., 2008a, 2008b). Van den Boogert \& Luttikholt (2004) by using Verticillium biguttatum, Wilson et al. (2008a) by applying T. harzianum and Lahlali \& Hijri (2010) by testing T. artroviride have been reported the efficiency of these antagonistic fungal biota agents against AG3-PT in potato. Bertagnolli et al. (1998) show that T. harzianum secretes the antimycotic compound trichodermin and a short peptide which inhibit mycelial growth of Rhizoctonia solani. Antagonistic activity by Penicillium species against $R$. solani has been observed, and it has been reported in relation to the production of toxic metabolites (Nicoletti et al., 2004). Madbouly et al. (2014) able to biocontrol of $R$. solani causing stem canker disease of potato by using rhizosphere fungal biota.

Non-pathogenic isolates of of $R$. solani have demonstrated potential as biological control agents (Tsror et al., 2001), including a naturally occurring hypovirulent isolate known as Rhs1A1. Rhs1A1 reduced black scurf and stem canker of potato when applied in field experiments (Bandy \& Tavantzis 1990 and Larkin \& Tavantzis (2013).

This in vitro test seems attractive as it shows clear and visible results (inhibition or lysis of the pathogen). It has also another advantage, i.e. relatively easy and quick to perform with large number of isolates. It is very suitable for selecting organisms with a particular mode of action, however it is considered a very poor predictor of the activity of any organism in the field because 
what happens in vitro cannot signify what exist in vivo (Andrews, 1985).

\section{Conclusion}

Since certain isolates of $T$. harzianum proved antagonistic to $R$. solani AG-3, these isolates will be further tested for their pathogenicity to $R$. solani on tuber seedling, under field conditions, in order to screen for the best biocontrol strains.

\section{Reference}

Adams, P.B. (1990) The potential of mycoparasites for biological control of plant diseases. Annu. Rev. Phytopathol. 28, 59-72.

Ahmad, J.S. and Baker, R. (1987) Rhizosphere competence of Trichoderma harzianum. Phytopathology, 77, 182 - 189.

Ahmad, I., Soomro, M.H., Khalid, S., Iftikhar, S., Munir, A. and Burney, K. (1995) Recent distributional trends of potato diseases in Pakistan. National Seminar on Research and Development of Potato Production in Pakistan, April 23 - 25, NARC, PSPDP, PARC, Islamabad, Pakistan.

Anderson, N.A. (1982) The genetics and pathology of Rhizoctonia solani. Annual Review of Phytopathology, 20, $329-347$.

Andrews, J.H. (1985) Strategies for selecting antagonistic microorganisms from the phylloplane. In: "Biological Control on the Phylloplane". C. E. Windels and S. E. Lindow (Ed.),pp.31 - 44. The American Phytopathological Society, St. Paul, MN.

Balali, G.R., Neate, S.M. and Scott, E.S. (1995) Anastomosis group and pathogenicity of isolates of Rhizoctonia solani from potato crops in Southern Australia. Plant Pathology, 44, 1050 - 1057.

Bandy, B.P. and Tavantzis, S.M. (1990) Effect of hypovirulent Rhizoctonia solani on Rhizoctonia disease, growth, and development of potato. American Potato Journal, 67, 189 - 199.

Beagle-Ristaino J.E. and Papavizas, G.C. (1985) Biological controls of Rhizoctonia stem canker and black scurf of potato. Phytopathology, 75, 560 - 564 .

Benhamou, N. and Chet, I. (1996) Parasitism of sclerotia of Sclerotium rolfsii by Trichoderma harzianum:
Ultrastructural and cytochemical aspects of the interaction. Phytopathology, 86, $405-416$.

Bénítez,T., Rincón, A.M., Limón,M.C. and Codón, A.C. (2004) Biocontrol mechanisms of Trichoderma strains. Int. Microbiol. 7, 249 - 260.

Bertagnolli, B.L., F. K. dal Soglio, J. and Sinclair, B. (1996) Extracellular enzyme profiles of the fungal pathogen Rhizoctonia solani isolate 2B12 and two antagonists. Bacillus megaterium strain B1 53-22 and Trichoderma harzianum isolate ThOO8, Possible correlations with inhibition of growth and biocontrol. Physiol. Molecular Plant Pathol. 48, $145-160$.

Bertagnolli, B.L. Daly, S. and Sinclair, J.B. (1998) Antimycotic compounds from the plant pathogen Rhizoctonia solani and its Antagonist Trichoderma harzianum. J. Phytopathology, 146, 131 - 135.

Brewer, M.T. and Larkin, R.P. (2005) Efficacy of several potential biocontrol organisms against Rhizoctonia solani on potato. Crop Protect, 24, 939-950. doi:10.1016/j.cropro.2005.01.012

Braun, S.D., Hofmann, J., Wensing, A., Weingart, H., Ullrich, M.S., Spiteller, D. and Volksch, B. (2010) In vitro antibiosis by Pseudomonas syringae Pss22d, acting against the bacterial blight pathogen of soybean plants, does not influence in planta biocontrol. J. Phytopathol. 158, 288 - 295.

Chand, T. and Logan, C. (1984) Antagonists and parasites of Rhizoctonia solani and their efficacy in reducing stem cancer of potato under controlled conditions. Trans. British Mycol. Soc. 83, 107 - 112.

Demirci, E. and Döken, M.T. (1993) Anastomosis groups and pathogenicity of Rhizoctonia solani Kühn isolates from potatoes in Erzurum-Türkiye. $J$. Turk. Phytopath. 22 (2-3), 95-102.

Elad, Y., Chet, I., Boyle, P. and Hems, Y. (1983) Parasitism of Trichoderma spp, on Rhizoctonia solani and Sclerotium rolfsii - scanning electron microscopy and fluorescence microscopy. Phytopathology, 73, $85-88$.

FAO (2008) International Year of the Potato 2008, New Light on a Hidden Treasure. Food and Agriculture Organization of the United Nations, Rome.

Gardes, M. and Bruns, T.D. (1993) ITS primers with 
enhanced specificity for basidiomycetes- application to the identification of mycorrhizae and rusts. Molecular Ecology, 2, 113-118. http://dx.doi. org/10.1111/j.1365294X.1993.tb00005.x

Gerhardson, B. (2002) Biological substitutes for pesticides. Trends Biotechnol. 20, $338-343$.

Ghisalberti, E.L. and Sivasithamparam, K. (1991) Antifungal antibiotics produced by Trichoderma spp. Soil. Biol. Biochem. 23, $1011-1020$.

Golińska, P. and Dahm, H. (2013) Antagonistic properties of Streptomyces isolated from forest soils against fungal pathogens of pine seedlings. Dendrobiology, 69, 87 - 97.

Groth, D.E. and Bond, J.A. (2006) Initiation of rice sheath blight epidemics and effects of application timing of azoxystrobin on disease incidence, severity, yield and milling yields. Plant Dis. 90, 1073-1078.

Grosch, R., Faltin, F., Lottmann, J., Kofoet, A. and Berg, G. (2005) Effectiveness of three antagonistic bacterial isolates to suppress Rhizoctonia solani Kuhn on lettuce and potato. Canadian Journal of Microbiology, 51, 345 - 353.

Grosch, R., Scherwinski, K., .Lottmann, J. and Berg, G. (2006) Fungal antagonists of the plant pathogen Rhizoctonia solani: Selection, control efficacy and influence on the indigenous microbial community. Mycological Research, 110, 1464 - 1474.

Huang, X., Zhang, N., Yong, X., Yang, X. and Shen, Q. (2012) Biocontrol of Rhizoctonia solani dampingoff disease in cucumber with Bacillus pumilus SQR-N43. Microbiol.Research, 167, 135 - 143.

Jager, G. and Velvis, H. (1985) Biological control of Rhizoctonia solani on potatoes by antagonists. 4. Inoculation of seed tubers with Verticillium biguttatum and other antagonists in field experiments. Netherlands J. Plant Pathol. 91, 49 - 63.

Jehtonen, M.J. (2009) Rhizoctonia solani as a potato pathogen variation of isolates in Finland and host response. University of Helsinki Finland, Academic Dissertation in Plant Pathology, p. 81.

Kumar, N., Mohandas, C., Nambisan, B., Kumar, D. R.S. and Lankalapalli, R.S. (2013) Isolation of proline-based cyclic dipeptides from Bacillus sp. N strain associated with rhabditid entomopathogenic nematode and its antimicrobial properties. World $J$. Microbiol. Biotechnol. 29, 355 - 364.

Kurzawińska, H. (2006) An interaction of potato crop soil fungi population on fungi responsible for superficial tuber diseases. J. Plant Prot. Res. 46, 339 - 346.

Lahlali, R. and Hijri, M. (2010) Screening, identification and evaluation of potential biocontrol fungal endophytes against Rhizoctonia solani AG3 on potato plants. FEMS Microbial Letters, 311, 152159.

Larkin, R. and Brewer, M. (2005) Effects of biological amendments on soil microbiology and soil borne potato diseases in different cropping systems. Phytopathology, 95 (6), S56 - S56.

Larkin, R.P. and Tavantzis, S. (2013) Use of biocontrol organisms and compost amendments for improved control of soilborne diseases and increased potato production. Am. J. Potato Res. 90, $261-270$.

Lee, C.Y., Cooksey, B.A.K. and Baehrecke, E.H. (2002) Steroid regulation of midgut cell death during Drosophila development. Dev. Biol. 250 (1), 101 111.

Li, Z.K., Pinson, S.R.M., Marchetti, M.A., Stansel, J.W. and Park, W.D. (1995) Characterization of quantitative trait loci (QTLs) in cultivated rice contributing to field resistance to sheath blight (Rhizoctonia solani). Theoretical and Applied Genetics, 91, 382 - 388 .

Madbouly, A.K., Boari, A., Vurro, M., Gebreel, H. M. and Abouzeid, M.A. (2014) Biocontrol of Rhizoctonia solani causing stem canker disease of potato using rhizosphere mold fungi. International Journal of Agronomy and Agricultural Research (IJAAR), 4 (6), $34-45$.

Melgarejo, P.C., Arrillo, R.M. and Sagasta, E. (1985) Mycoflora of peach twigs and flowers and it is possible significance in biological control of Monilinia laxa Transactions of the British. Mycological Society, $\mathbf{8 5}$ (2), $313-317$.

Nicoletti, R., De Stefano, M. and De Stefano, S. (2004) Antagonism against Rhizoctonia solani and fungitoxic metabolite production by some Penicillium isolates. Mycopathologia, 158, 465474. 
Ogoshi, A. (1987) Ecology and pathogenicity of anastomosis and interspecific groups of Rhizoctonia solani Kuhn. Annual Review of Phytopathology, 25, 125- 143.

Papavizas, G.C. (1985) Trichoderma and Gliocladium: biology, ecology, and potential for biocontrol. Annu. Rev Phytopathol. 23, 23 - 54.

Papavizas, G.C. and Lumsden, R.D. (1980) Biologicalcontrol of soil-borne fungal propagules. Annu. Rev. Phytopathol. 18, $389-413$.

Royse, D.J. and Ries, S.M. (1978) The influence of fungi isolated from peach twigs on the pathogenicity of Cytospora cincta. Phytopathology, 68, 603 - 607 .

Tsror, L., Barak, R. and Sneh, B. (2001) Biological control of black scurf on potato under organic management. Crop Protect. 20, 145- 150. 10.1016/ S0261-2194(00)00124-1

Tunlid, A., Hoitink, H.A.J., Low, C. and White, D.C. (1989) Characterization of Bacteria That Suppress Rhizoctonia Damping- Off in Bark Compost Media by Analysis of Fatty Acid Biomarkers. Applied and Environ Microbiol. 55 (6), 1368 - 1374.

Turhan, G. (1990) Further hyperparasites of Rhizoctonia solani Kühn as promising candidates for biological control. J. Plant Dis. Protect. 97, 208 - 215.

Van den Boogert, P.H.J.F. (1996) Mycoparasitism and biocontrol In: "Rhizoctonia Species: Taxonomy, Molecular Biology, Ecology, Pathology and Disease Control". Sneh, B, Jabaji-Hare, S., Neate, S., Dijst,G. (Ed.), pp. 485 - 493. Kluwer Academic Publishers, Dordrecht.

Van den Boogert, P.H.J.F. and Luttikholt, A.J.G. (2004) Compatible biological and chemical control systems for Rhizoctonia solani in potato. Eur. J. Pl. Pathol. 110, 111-118.

Vinale, F., Sivasithamparam, K., Ghisalberti, E.L., Marra, R., Woo, S.L. and Lorito, M. (2008) Trichoderma-plant-pathogen interactions. Soil Biol. Biochem. 40, 1-10. doi:10.1016/j.soilbio.2007.07. 002
Waksman, S.A. (1927) "Principles of Soil Microbiology". Bailler, Tindall and Cox, London.

Wang, H., Wen, K., Zhao, X., Wang, X., Li, A. and Hong, H. (2009) The inhibitory activity of endophytic Bacillus sp. strain CHM1 against plant pathogenic fungi and its plant growth-promoting effect. Crop Prot. 28, $634-639$.

Wensing, A., Braun, S.D., Buttner, P., Expert, D., Volksch, B., Ullrich, M.S. and Weingart, H. (2010) Impact of siderophore production by Pseudomonas syringae pv. syringae 22d/93 on epiphytic fitness and biocontrol activity against Pseudomonas syringae pv. glycinea 1a/96. Appl. Environ. Microbiol. 76, $2704-2711$.

Wijesinghe, C.J., Wilson Wijeratnam, R.S., Samarasekara, J.K. and Wijesundera, R.L. (2010) Identification of Trichoderma asperellum from selected fruit plantations of Sri Lanka. J. Natn. Sci. Foundation Sri Lanka. 38, (2), 125 - 129.http:// dx.doi.org/10.4038/jnsfsr.v38i2.2037

Wilson, P.S., Ahvenniemi, P.M., Lehtonen, M.J., Kukkonen, M., Rita, H. and Valkonen, J.P.T. (2008a) Biological and chemical control and their combined use to control different stages of the Rhizoctonia disease complex on potato through the growing season. Ann. Appl. Biol. 153, 307- 320. doi:10.1111/j.17447348.2008.00292.x

Wilson, P.S., Ketola, E.O., Ahvenniemi, P.M., Lehtonen, M.J. and Valkonen, J.P.T. (2008b) Dynamics of soil-borne Rhizoctonia solani in the presence of Trichoderma harzianum: effects on stem canker, black scurf and progeny tubers of potato. Plant Pathol. 57,152 - 161. doi:10.1111/j.1365 - 3059. 2007.01706.x

White, T.J., Bruns, T., Lee, S. and Taylor, J. (1990) Amplification and direct sequencing of fungal ribosomal RNA genes for phylogenetics. In: " $P C R$ Protocols: A guide to Methods and Applications" Innis, M.A., Gelfand, D.H., Sninsky, J.J., White, T. J. (Ed.), Academic Press, San Diego, 315322.http:// dx.doi.org/10.1016/B978-0-12-372180-8.50042-1 


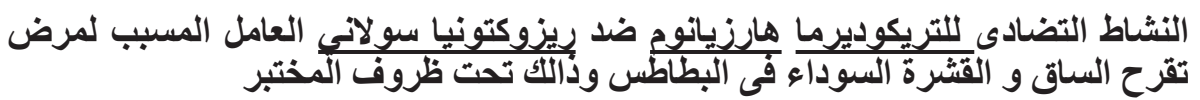

محسن السيد إبراهيم

قسم النبات ـ كلية العلوم- جامعة بورسعيد - بور سعيد -42524 ـ مصر.

تعتبر البطاطس (سو لانوم توبيروسوم) في مصر واحدة من أهم المحاصيل النباتية وكذللك فى العديد من البلدان

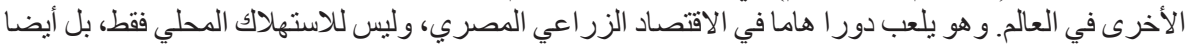

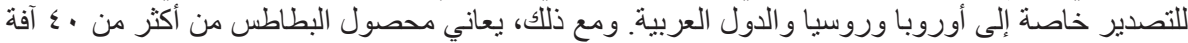

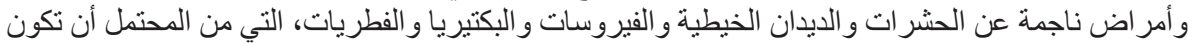

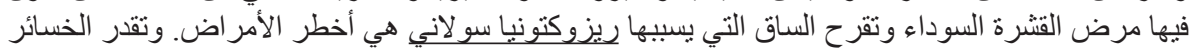

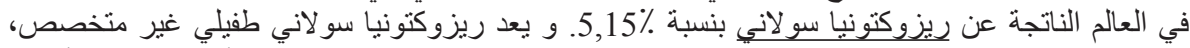

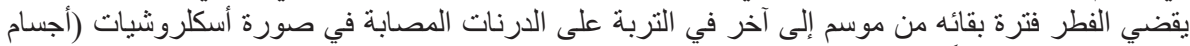

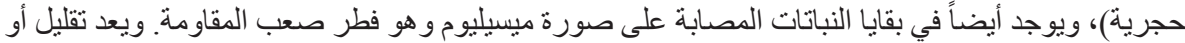

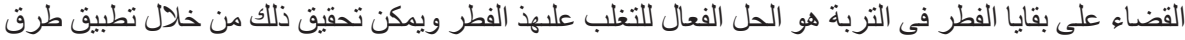

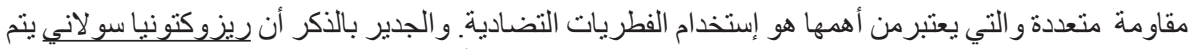

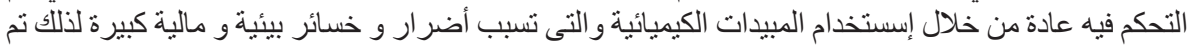

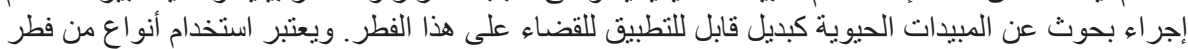

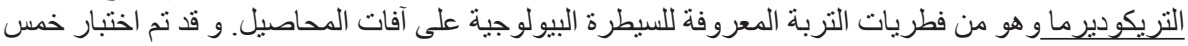

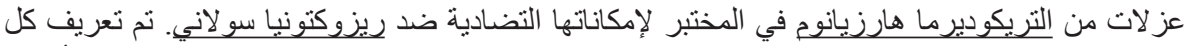

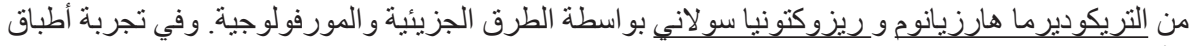

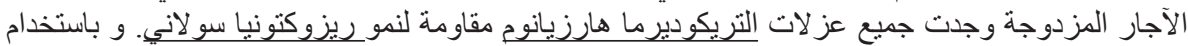

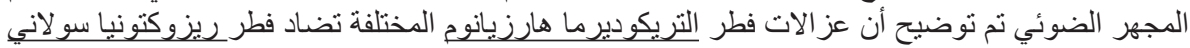

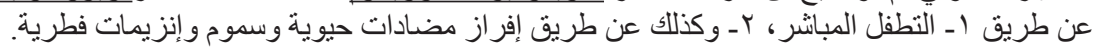

